\title{
THE DESCENT OF MAN
}

\author{
A precarious position.
}

\section{BY CHRISTOPH WEBER}

$\mathrm{F}$ or one moment, the afternoon air suspends me 50 feet above the earth. For one moment, I am free.

An apple branch absorbs the shock of my landing. I dip my brush into the basket at my hip and pull out the black bristles, now dusted in yellow pollen. They say that bees were black and yellow, so I guess the colours are fitting.

I dab a white flower, dust some yellow on the stigmas, and move on - blossom to blossom, branch to branch.

The fruit trees grow tall here in Washington. The skinnies used to stunt them for easy picking, but after waking us, they tweaked the trees to utilize vertical space.

I leap. My muscled legs explode like pistons in the skinnies' useless old engines. I land on a stout branch; it flexes, then lobs me back into space. Free again.

I extend a thick, calloused hand, grasp the smooth red-barked limb in a handshake of trust, and redirect my swing. I do a little half turn, hope the other old ones are watching, and land backwards on the next branch.

"March!"

Someone was watching. Not an old one, though. It's Maestro, the skinny who names us all after the month he buys us.

"March, where is your rope?" he demands, staggering towards my tree, rifle in hand. Drunk, no doubt.

Tobacco juice hangs from his mouth like a black string. My lips curl in revulsion. He notices. He may be revolting, with a forehead big as the Moon, but he doesn't miss much.

"Do I disgust you?" he asks, spitting a thick black rope.

I say nothing. Just size up his spindly arms. You may be tall, but I could break you in half, skinny.

The skinnies didn't wake us to climb trees. They woke us to cure their diseases, to fix their weak bones. They woke us for the same reason skinnies do everything - to help themselves. They'll tell you that it was out of some innate curiosity, but satisfying that curiosity is just another way they help

$\rightarrow$ NATURE.COM Follow Futures: @ @NatureFutures f go.nature.com $/ \mathrm{mtoodm}$ themselves.

They were wrong about us - we're better climbers than they imagined, more suited to trees than they thought. We have the strength to climb and leap, and the bones to support rough landings, occasional falls. "More like the rest of Hominidae than we expected," they said. "Less like us than we thought." Like that's a bad thing. The skin-

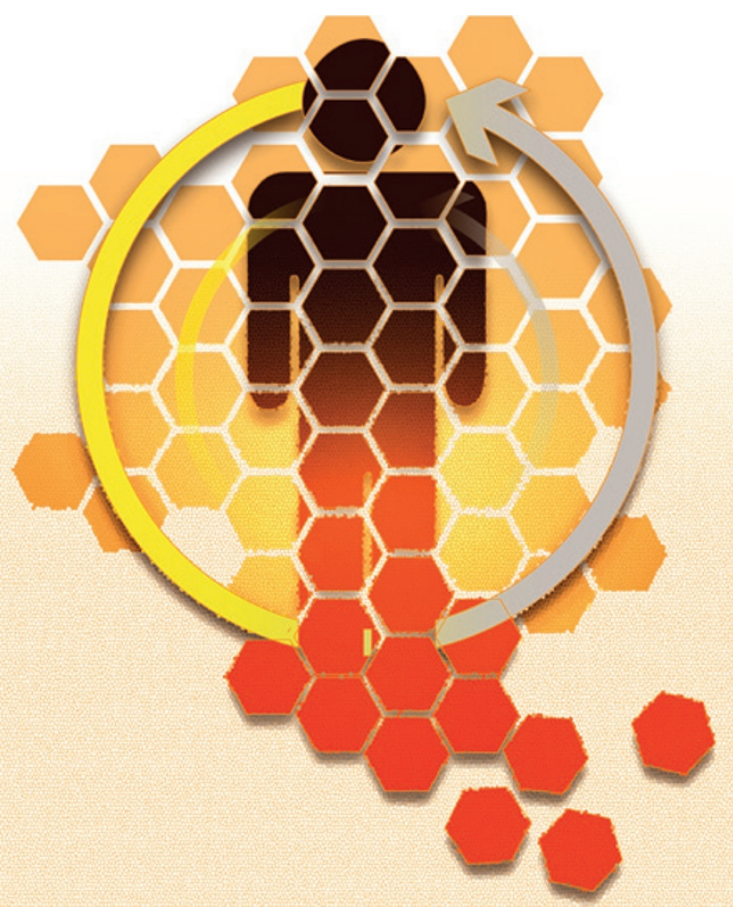

nies used to enslave their own kind. When they needed labour to do the work of bees, it shouldn't have surprised anyone they'd turn to us.

There are some skinnies who oppose it, mostly in the South where it's too dry to grow much anymore. It's easy for them to talk about emancipation when they don't need us, not like the Northwest does. This is the last good growing land, and good growing requires pollinators. So here I am, 50 feet up in a tree with an ugly skinny yelling at me.

"March, I'm only gonna ask you one more time. Where is your rope!?"

"Don't need it." I could climb this tree with my eyes closed.

Maestro hoots. "Don't need it! March, I own you - remember that! You fall from that tree, you damage my property. You know what I do to stonelickers that break my things?"

I stare back in silence.

"March, are you mean-muggin' me? Get down here. Now!"

I stand still. Maestro lifts his rifle. I know
I should come down, but in this small act of defiance I can see Maestro realizing that he doesn't really own me, and I can't help but grin. Anyway, he won't actually shoot me. I'm too useful.

The applewood next to my face explodes in a starburst of splinters. I wipe my eyes. Blink. Look down the barrel of Maestro's rifle. Dive. The wood reverberates with intercepted shot. I duck behind the trunk. Is Maestro aiming to kill? It doesn't matter. He's drunk and angry and the tree is exploding around me. His shots are close, too close. I stand with my back to the trunk and see April under her tree, looking up at me with wide, worried eyes.

I peek around the bole. Maestro's reloading. His head is down.

Something in the oldest, deepest recess of my mind comes alive and takes control. When my feet leave the powdery red bark, it's as if they belong to someone else. I slip into space and begin the descent of a hunter ambushing prey.

Maestro looks up just in time to see my heavy knees meet his face.

There is a crunching sound. A blossom of white pain in my legs. The impact was hard, even for my thick bones. I roll over. See Maestro's face. Understand the sound was not from my legs. I stagger to my feet as April and September Two run over. September Two looks down at Maestro, shudders and picks up his rifle. April throws her arms around me, buries her face in my neck. When she looks up, her eyes glisten from under a strong brow, out from a face full of strength. A face full of pride. The face of an old one.

Old one - that's what we call ourselves. Skinnies like Maestro call us stonelickers. But if you find a decent skinny, which doesn't happen much, he might call us by another name.

Neanderthal.

The other old ones gather round and next thing I know we're running, all together, for the edge of the orchard where the dark forest beckons, offering concealment from catchers. We're running from skinnies, running into the ancient wood's embrace.

For the first time in our lives, we are running free.

Christoph Weber is an arborist in Reno, Nevada. Despite spending much of his life in trees, he is fully human. 